UDC: 616.136-007.64-083.98 Crnokrak B, i sar. Uloga tima HMP kod RAAA.

NČ UM Halo 194. 2019;_25(3): 155-164.

Rad primljen: 22.04.2019

Prihvaćen: 12.12.2019.

\section{Korespodencija: \\ Bogdan Crnokrak \\ KBC Bežanijska kosa \\ Cara Dušana 254 \\ 11080 Zemun \\ Srbija}

Tel. 011/30-10-777

E-mail: bcrnokrak@yahoo.com
PREGLEDNI RAD

\section{ULOGA TIMA HITNE MEDICINSKE POMOĆI U INICIJALNOM ZBRINJAVANJU I TRANSPORTU BOLESNIKA SA RUPTUROM ANEURIZME ABDOMINALNE AORTE}

\author{
Bogdan CRNOKRAK, Nataša ČOLAKOVIĆ, Darko ZDRAVKOVIĆ, Borislav \\ TOŠKOVIĆ, Marija ZDRAVKOVIĆ
}

KBC Bežanijska kosa, Beograd, Srbija

\begin{abstract}
SAŽETAK
Ruptura aneurizme abdominalne aorte (RAAA) je akutno kliničko stanje koje zahteva neodložan hirurški tretman. Za postavljanje prave dijagnoze i definitivno zbrinjavanje ovog kliničkog stanja neophodni resursi prevazilaze mogućnosti službe Hitne medicinske pomoći (HMP). Ukoliko se rano, još pri prvom kontaktu sa osobom, posumnja na RAAA, značajno se skraćuje vremenski period između rupture aneurizme, ulaska u operacionu salu i definitivnog hirurškog zbrinjavanja, što ima presudnu ulogu u preživljavanju bolesnika. Otuda se akcentuje uloga službe HMP u zbrinjavanju RAAA, počevši od adekvatnog inicijalnog tretmana do transporta u ustanovu u kojoj će se izvesti hitna hirurška procedura. Ne postoji standardizovan i opšte prihvaćen sistem inicijalnog zbrinjavanja, kao ni sistem transporta pacijenata sa RAAA koji bi bio univerzalno primenjiv u svim zdravstvenim sistemima, ali timskim radom i identifikacijom mogućih problema na svim nivoima u procesu zbrinjavanja, moguće je većem broju bolesnika pružiti šansu da prežive ovo stanje za koje je visoka smrtnost gotovo sinonim.
\end{abstract}

Ključne reči: ruptura aneurizme, transport, hitna medicinska pomoć

\section{Uvod}

Rupturu aneurizme abdominalne aorte (RAAA) možemo definisati kao krvarenje izvan adventicije dilatiranog aortnog zida, koje ujedno predstavlja i nesposobnost aortnog zida da se suprotstavi povećanom pritisku krvi kome je izložen. Ovo potencijalno životno-ugrožavajuće kliničko stanje, zbog povećanog rizika od letalnog ishoda, zahteva neodložan hirurški tretman.

Uprkos činjenici da je prošlo skoro 70 godina od prvih izveštaja o rezultatima operativnog lečenja rupturirane AAA [1], te drastičnom napretku tehnologije u oblasti medicine, smrtnost je i dalje jako visoka. Procenjuje se da je ukupni mortalitet među pacijentima koji su u bolnicu stigli živi između 40\% i $60 \%$ $[2,3]$. Međutim, ako se uračunaju i podaci dobijeni tek na autopsiji za bolesnike koji nisu živi ni stigli do bolnice, mortalitet je oko 90\% [4]. Preoperativni i perioperativni mortalitet posledica su akutnog iskrvarenja, dok je visok postoperativni mortalitet posledica komplikacija kao što je infarkt miokarda, bubrežna insuficijencija i razvoj multiorganske insuficijencije (multiple organ failure-MOF) [5].

Prema prostoru u koji ističe krv iz aorte, sve RAAA možemo grubo podeliti u dve grupe. Prva je slobodna, intraperitonealna RAAA a druga je retroperitonealna RAAA. Postoje i retke rupture u druge anatomske prostore kao što je lumen želuca, tankog ili debelog creva te u donju šuplju venu, kada govorimo o primarnoj aortogastričnoj, primarnoj aortoenteričnoj ili primarnoj aortokavalnoj fistuli. Intraperitonealne rupture u peritonealnu šupljinu imaju drastično lošiju prognozu zbog dramatično brzog gubitka velike količine krvi. Ruptura aneurizme u retroperitoneum, zbog sposobnosti retroperitonealnog tkiva da "napravi" privremenu tamponadu čime se redukuje volumen i brzina gubitka krvi, može obezbediti potrebno vreme da se takvom pacijentu spasi život.

Postojanje AAA ne znači da istovremeno postoji i akutno stanje. Šansa da aneurizma rupturira zavisi od velikog broja faktora među kojima su kao najznačajniji identifikovani dijametar aneurizme i pritisak koji trpi zid aorte u kontekstu njegove mogućnosti da 
se tom pritisku odupre. Eksperimentalnim in vitro uslovima je definisano da je sila koja je potrebna da razori zid zdrave aorte $121 \mathrm{~N} / \mathrm{cm} 2$ dok je sila koja je potrebna da razori zid dilatirane aorte značajno manja i iznosi samo $65 \mathrm{~N} / \mathrm{cm} 2[6,7]$.

Važno je razlikovati simptomatsku od rupturirane aneurizme. Simptomatska aneurizma je ona kod koje promene u zidu aorte izazivaju bol, ali još uvek nema rupture. Bol kod nerupturirane AAA se dovodi u vezu sa akutnim širenjem zida, intramuralnom hemoragijom, degeneracijom zida, krvarenjem u parijetalni tromb, i može prethoditi rupturi. Kao takav ne sme biti ignorisan, već naprotiv zahteva brzo i adekvatno reagovanje i operativno zbrinjavanje pacijenta u cilju prevencije rupture. Prognoza kod operisanih simptomatskih AAA je značajno bolja nego kod rupturiranih, ali i dalje gora nego kod elektivno operisanih bolesnika [8].

Jako je teško precizno utvrditi incidencu RAAA u opštoj populaciji, jer većina nacionalnih registara i registara pojedinih medicinskih centara (ukoliko uopšte postoje) ne uzima u obzir rezultate obdukcionih nalaza u celosti. Većina njih registruje samo one slučajeve koji su vezani za odgovarajući medicinski centar, što dovodi do podcenjivanja učestalosti RAAA u opštoj populaciji. Takođe, lošiji ishodi se pogotovo među starijom populacijom češće vezuju za akutno srčano oboljenje nego za RAAA što dodatno podcenjuje smrtnost od RAAA.

Smanjenje smrtnosti vezanih za RAAA, najpre u SAD a zatim i u drugim zemljama postignuto je uvođenjem manje invazivnih endovaskularnih procedura na abdominalnoj aorti što je omogućilo da se bolesnici koji zbog komorbiditeta ranije nisu selektovani za klasične operacije operišu, čime je smanjen ukupni broj bolesnika sa aneurizmama. Sa druge strane, metoda endovaskularnog zbrinjavanja RAAA poslednjih godina je promovisana ne samo kao manje invazivna procedura već $\mathrm{i}$ zato što se izbegava klemovanje aorte čime se redukuje jedan od najvećih perioperatvnih rizika vezanih za splahničku ishemiju i ishemiju donje polovine tela [9-11] .

\section{Zbrinjavanje pacijenata sa RAAA}

Lečenje pacijenata sa RAAA zahteva zajednički i koordinisani rad između specijalista različitih oblasti u cilju pravovremenog postavljanja dijagnoze, adekvatnog preoperativnog i perioperativnog tretmana, uspešnog hirurškog lečenja i dobre postoperativne ne- ge. U ovom lancu obaveza i odgovornosti važno mesto zauzimaju ekipe Hitne medicinske pomoći (HMP) [12] koje poštujući pravila struke i važeće vodiče dobre kliničke prakse pružaju osnovu adekvatnog tretmana takvih pacijenata kada je faktor vremena presudan za preživljavanje.

\section{Kako što ranije postaviti pravu dijagnozu?}

Bolesnik sa RAAA ostvaruje prvi medicinski kontakt sa članovima ekipe HMP. Od presudnog je značaja da se tokom prvog pregleda bolesnika barem posumnja na RAAA, kako bi se donela odluka o transportu pravog bolesnik, u pravo vreme, na pravom mestu.

Tipični simptomi i znaci za RAAA su naglonastali bol u leđima ili trbuhu, hipotenzija i palpabilno pulsirajuća masa u epi i/ili mezogastrijumu $[13,14]$. Kod izrazito gojaznih [15] ili hipotenzivnih bolesnika, palpiranje pulsirajuće mase može biti otežano ili neizvodljivo. Što je dijametar RAAA veći, veća je i šansa de se pulsirajuća mase može napipati.

Retke rupture u neki segment digestivnog trakta manifestuju se hematemezom ili melenom, dok se rupture u donju šuplju venu manifestuje kongestivnom srčanom slabošću, nabreklim venama vrata i trilom u abdomenu. Sve ove simptome treba sagledati pri trijaži bolesnika za urgentno zbrinjavanje i transport.

\section{Diferencijalna dijagnoza}

Ako osoba ili rodbina pacijenta ima saznanje da pacijent ima dijagnostikovanu AAA, pojava gore navedenih simproma uvek treba da implicira da se dijagnostičkim algoritmom prvo isključi ili dokaže RAAA.

Kod pacijenata starijih od 50 godina sa hipotenzijom i/ili sinkopom diferencijalno-dijagnostički treba isključiti dijagnozu RAAA. Ovo je od krucijalnog značaja za preživljavanje ovako kritičnih bolesnika zbog visoke stope smrtnosti i kratkog vremenskog intervala neophodnog za njihovo definitivno zbrinjavanje. Diferencijalno dijagnostičke nedoumice mogu nastati kod svakog akutnog stanja u trbuhu praćeno bolom, akutne bubrežne kolike, akutnog pankreatitisa, bilijarnne kolike sa ili bez akutnog holecistitisa, peptičke ulkusne krize sa ili bez perforacije, divertikulitisa, akutne mezenterijalne ishemiju. Takođe, diferencijalno dijagnostički treba isključiti i ostala klinička stanja koja se ne dešavaju u trbuhu ali po 
kliničkim manifestacijama liče na RAAA kao što je infarkt miokarda i akutni lumbalni sindrom [16].

Studije su pokazale da je oko 23\% RAAA rano prepoznato od strane lekara koji je prvi pregledao bolesnika [17] a procenat pogrešnih dijagnoza je varirao od $16 \%$ do $60 \%$ [18] i najčešće se sumnjalo na renalnu koliku. U tom kontekstu je važno napomenuti da je prva manifestacija renalne kolike kod ljudi starijih od 50 godina izuzetno retka. Klasična trijada simptoma: pulsatilna masa, bol i hipotenzija su bile prisutne kod 9\% bolesnika kojima je postavljena pogrešna dijagnoza, a kod svega $34 \%$ bolesnika je praviIno dijagnostikovana RAAA [18] od strane lekara koji je prvi pregledao pacijenta. Postojanje pulsirajuće mase u trbuhu je detektovano kod $72 \%$ bolesnika koji su pravilno i $26 \%$ onih koji nisu pravilno dijagnostikovani kao RAAA iz čega proizilazi zaključak da je odsustvo pulsirajuće mase u abdomenu glavni razlog neprepoznate dijagnoze pri prvom kontaktu lekara $\mathrm{i}$ ovakvih pacijenta [18].

Ukoliko se na osnovu anamnestičkih podataka i/ili kliničkog pregleda posumnja na RAAA, od krucijalne važnosti je neodložan transport bolesnika u ustanovu koja ima tehnološke i ljudske resurse za adekvatno zbrinjavanje navedeg kliničkog stanja.

\section{Dijagnostički algoritam}

Kliničkim pregledom bolesnika se može postaviti sumnja da se radi o RAAA, ali za postavljanje definitivne dijagnoze RAAA je neophodno sprovesti neki od vizuelizacionih dijagnostičkih modaliteta. Optimalna terapijska strategija mora biti doneta da svakog pacijenta ponaosob [19].

EHO abdomena je široko dostupna, brza, neinvazivna dijagnostička procedura i lekari koji rade u HMP i poseduju EHO aparat treba da budu obučeni za brzu orjentaciju i dijagnostiku RAAA. FAST (Focused Assessement with Sonography in Trauma) protokol služi za brzu detekciju tečnih kolekcija u trbuhu i koristi se u urgentnoj službi za procenu dijametra i evantualne RAAA [20]. EHO pregledom se može za manje od 5 minuta utvrditi dijametar aorte, uočiti retroperitonealni hematom kao i slobodna tečnost $u$ trbuhu, ali se ovom dijagnostičkom metodom ne može isključiti RAAA [21].

Dijagnostička metoda izbora za postavljanje definitivne dijagnoze RAAA je MSCT aortografija. Njome se može vizuelizovati aneurizma, mesto rupture, retroperitonealni hematom, prateća klinička stanja i anatomski odnosi, što zajedno može biti važno za planiranje operativnog lečenja. Vizuelizacija retroperitonealnog krvarenja je zlatni standard za dijagnozu RAAA i ona je $100 \%$ specifična za ovo kliničko stanje sa negativnom prediktivnom vrednosti od $89 \%$ $[22,23]$. Bolesnike sa sumnjom na RAAA ne treba transportovati u ustanovu koja u datom momentu nema mogućnost izvođenja MSCT aortografije i ekipe HMP moraju biti upoznate sa ovom informacijom.

Postavlja se pitanje koliki je vremenski interval od pojave prvih simptoma RAAA do mogućeg letalnog ishoda bolesnika. Studija sprovedena na pacijentima koji su bili suviše stari za operativno lečenje ili su imali suviše teške komorbiditete je pokazala da ovo vreme prosečno iznosi 16 sati [24]. Dva sata nakon prijema u bolnicu umrlo je $13 \%$ bolesnika a prosečno vreme između prijema u bolnicu i smrti bilo je 11 sati. Ovo govori o tome da se kod većine pacijenata sa RAAA ima dovoljno vremena za sprovođenje dijagnostičkih procedura i planiranje operativnog lečenja. U Velikoj Britaniji se 33\% bolesnika koji imaju RAAA transportuje iz drugih bolnica, a da prosečno vre-me između dolaska u bolnicu i ulaska u operacionu salu iznosi 159 minuta [25].

Ukoliko MSCT aortografija nije učinjena $u$ ustanovi iz koje se bolesnik transportuje a bolesnik je pri prijemu hemodinamski stabilan, $\mathrm{u}$ većini slučajeva ima se dovoljno vremena za MSCT aortografiju. S druge strane, bez obzira što je bolesnik inicijalno stabilan sve vreme tokom transporta i izvođenja MSCT, moraju biti ispoštovane mere monitoringa vitalnih parametara jer takvi bolesnici lako postaju hemodinamski nestabilni.

\section{Transport u adekvatnu ustanovu}

Uspostavljanje protokola ili algoritma za urgentni/hitni tretman bolesnika sa RAAA je bazično za optimizaciju rezultata [26]. U pojedinim zdravstvenim sistemima gde postoje jasno definisani protokoli za zbrinjavanje RAAA, njihovom implementacijom $u$ kliničkoj praksi, mortalitet bolesnika u prvih 30 dana iznosi $18 \%$. Nasuprot tome, u sistemima u kojima ne postoje protokoli, mortalitet u navedenom periodu iznosi 32\% [27,28]. Slično ovome, zaključak EUROASPIRE V studije je da upadljiva varijabilnost u zbrinjavanju pacijenata između različitih zemalja i centara, može biti umanjena adekvatnom edukacijom $i$ medicinskih profesionalaca i pacijenata o neohodnosti 
promene stila života osoba koje su u povećanom riziku za razvoj ovog akutnog stanja [29].

Transport pacijenta u ustanovu u kojoj se RAAA ne može dijagnostikovati i zbrinuti, po pravilu predstavlja veliki gubitak u vremenu i drastično manje šanse da takav pacijent preživi. U našoj zemlji, svega nekoliko zdravstvenih ustanova zahvaljujući svojim ljudskim resursima i tehničkoj opremljenosti, mogu bez odlaganja da postave dijagnozu i zbrinu pacijente sa RAAA. U tom smislu važno je definisati redosled i dinamiku aktivnosti za svaki pojedinačni zdravstveni segment $u$ lancu zbrinjavanja pacijenatana sa RAAA.

Presudni faktor u uspostavljanju funkcionalnog sistema je komunikacija, ne samo intertimska u svakoj pojedinačnoj fazi zbrinjavanja, već i heterotimska u različitim fazama zbrinjavanja bolesnika. Mogu se identifikovati najmanje tri tima (grupe timova) koji se $\mathrm{u}$ različitim fazama uključuju u zbrinjavanje bolesnika sa RAAA. Na samom početku je to tim HMP, zatim tim u urgentnom prijemu-odeljenju za reanimaciju stacionarne ustanove koji prihvata bolesnika i u dogovoru sa trećim, vaskularno hirurškim timom, definiše dalje korake u dijagnostičko-terapijskom algoritmu zbrinjavanja ovih bolesnika. Pored ova tri tima, koji čine osnovu u vremenskoj liniji zbrinjavanja, u zbrinjavanje je uključen i tim radiologa sa zadatkom da kod stabilnih bolesnika potvrde dijagnozu i zahvaljujući imidžing tehnici omoguće hirurškom timu planirnje operativnog lečenja i svakako anesteziološki tim koji neposredno priprema i vodi bolesnika tokom hirurške intevencije. Uz to, treba spomenuti i dežurni tim zdravstvene ustanove koja po svojim tehničkim kapacitetima i ljudskim resursima nije $u$ mogu-ćnosti da zbrine pacijenta sa RAAA a koji mora biti uključen u liniju komunikacije, jer je iz svakodnevne prakse poznato da jedan broj pacijenata sa RAAA dospe upravo u hitne službe ovakvih ustanova. Jasno je i da neometana intertimska komunikacija čini osnovu sistema zbrinjavanja pacijenata sa RAAA. Posebnu poteškoću predstavlja činjenica da je jedino unutar službe HMP, zahvaljujući postojanju koordinatorske službe, moguće u svakom trenutku pratiti i koordinisati aktivnosti, anticipirati moguće prepreke $\mathrm{i}$ pacijenta predati sledećem timu u nizu tj. timu u hitnom prijemu-službi za reanimaciju. Ostali timovi u većini slučajeva za pacijenta saznaju tek po njegovom dovoženju od strane HMP u bolničku službu za zbrinjavanje hitnih stanja. Prva prepreka koju treba savladati je da pri postavljanju sumnje na moguću RAAA, tim HMP obavesti tim u hitnom prijemu odgovarajuće bolničke ustanove o dovoženju takvog bolesnika, da bi sve bilo spremno za prihvatanje bolesnika i da bi vremenska distanca između prijema i preduzimanja daljih dijagnostičko-terapijskih sekvenci bila što kraća. Isto pravilo važi i za tim u hitnoj službi ustanove koja nije u mogućnosti da zbrine ove bolesnike već ih šalje u drugu ustanovu koja to može. Iz prethodno rečenog, zaključujemo da oba ova tima moraju raspolagati informacijom koja ustanova u datom trenutku ima kapacitete za zbrinjavanje ovakvih bolesnika. Paralelno sa obaveštavanjem ciljne ustanove od strane HMP o dovoženju pacijenta sa RAAA, neophodna je I aktivacija vaskularnog hirurškog tima. Postavlja se pitanje ko zapravo obaveštava vaskularni hirurški tim o dolasku bolesnika sa RAAA, da li odeljenje hitne službe odgovarajuće ustanove u koju je najavljen dolazak ovog bolesnika ili tim službe HMP odnosno tim u hitnom prijemu ustanove koja bolesnika sa RAAA ne može zbrinuti, ili možda i jedni i drugi.

Tokom transporta ovih bolesnika, bilo od kuće ili iz druge zdravstvene ustanove, obavezna je lekarska pratnja sposobna za preduzimanje mera reanimacije, bez obzira što je u trenutku smeštanja u sanitetsko vozilo bolesnik bio hemodinamski stabilan.

Sve vreme, od postavljanja sumnje na RAAA pa do isključenja ili potvrde dijagnoze i predaje bolesnika sledećem timu u nizu, bolesnici ne smeju da načine ni jedan dodatni korak, Osnova je da se oni do sanitetskog vozila obavezno prenose nosilima ili u kardiološkoj stolici a tokim transporta se smeštaju i stabilizuju na transportnim nosilima. Tokom transporta, neophodan je kontinuirani monitoring vitalnih funkcija. Ukoliko je dijagnoza postavljena na osnovu MSCT aortografije u bolničkoj ustanovi u kojoj se bolesnik ne može zbrinuti, važno je zajedno sa ostalom dokumentacijom poslati i snimke na CD-u ukoliko ih nije moguće proslediti u elektronskoj formi [30].

Od presudne važnosti za adekvatan i istovetan tretman bolesnika, kao i za kasniju evaluaciju i anali$\mathrm{zu}$, te pronalaženje slabih tačaka u sistemu, jeste $\mathrm{i}$ uspostavljanje formulara koji po tipu Kliničkog puta leka treba da prati ovakve bolesnike. Ovim dokumentom je mogućnost nastanka propusta $i$ grešaka $u$ nekoj od faza pružanja medicinske pomoći bolesniku svedena na minimum, izbegnuta je mogućnost da se neki ključni podatak ne prenese između timova, takođe, ostaje trajan trag o preduzetim merama i aktivnostima koje je moguće meriti, analizirati i korigovati ukoliko se neka mera pokaže nedovoljno uspe- 
šnom. Dokument bi se predavao iz ruke u ruku lekaru sledećeg tima u nizu. Jedan primerak popunjenog dokumenta ostaje lekaru onog tima koji je bolesnika predao.

Transfer bolesnika iz jedne ustanove $u$ drugu povećava vremensku distancu do ulaska u operacionu salu, tako da je mortalitet pacijenata koji su transportovani iz drugih bolnica nešto veći u prva $24 \mathrm{~h}$, ali je dužina lečenja u jedinici intenzivne nege kao i ukupna dužina hospitalizacije slična za obe grupe [31].

\section{Osnovni principi reanimacije i tretmana tokom prvog kontakta i transporta:}

U cilju brze evaluacije stanja bolesnika, koju inicijalno treba da učini lekar HMP za svakog bolesnika sa sumnjom naRAAA, koristi se:

- $\mathrm{ABC}$ (airway, breathing, and circulation) protokol,

- procena opšteg stanja bolesnika,

- procena vitalnih znakova.

Bolesniku treba plasirati dve periferne venske linije. Centralni venski kateter i arterijska linija se plasiraju tek u operacionoj sali. Permisivna hipotenzija ili hipotenzivna hemostaza označava princip izbegavanja ekstenzivne nadoknade tečnosti ukoliko je bolesnik svestan, vrednost sistolnog pritiska između 70 i $90 \mathrm{~mm} \mathrm{Hg}$ i nema znakova ST depresije na EKGu [32,33].

Intenzivne resuscitacione mere kod hipotenzivnih bolesnika sa RAAA ponekad mogu da budu čak i fatalne [34-36]. Agresivna nadoknada volumena kod takvih bolesnika može imati za posledicu da nakon privremeno savladane tamponade $\mathrm{u}$ retroperitoneumu dođe do novog krvarenja, koje ukoliko se dogodi pre dolaska bolesnika u operacionu salu, može imati letalan ishod. Tako je postalo jasno da je permisivna hipotenzija od presudne važnosti u toku transporta i dijagnostike ovih pacijenata. Ovde se može iskoristiti iskustvo transporta bolesnika sa teškom traumom kod kojih je evidentirano veće preživljavanje ako je nadoknada tečnosti bila odložena do trenutka ulaska u operacionu salu [37]. Cilj kojem treba težiti je održavanje bolesnika svesnim, prevencija infarkta miokarda i sistolni pritisak u granicama od oko $80 \mathrm{~mm} \mathrm{Hg}$ a nikako preko $100 \mathrm{~mm} \mathrm{Hg}$. Mortalitet bolesnika kojima je tokom transporta primenjena agresivna resuscitaciona terapija ekstenzivnom nadoknadom volumena je bila od $78 \%$ do $90 \%$ [3]. Tokom transporta, bolesniku se mogu parenteralno dati lekovi za kontrolu arterijske tenzije i za kupiranje bola, a sve to u cilju prevencije fatalnog iskrvarenja. Starije osobe sa brojnim komorbiditetima slabije tolerišu hipotenziju ali još uvek nema objavljenih studija koje se bave pitanjem resuscitucije tokom transporta ove populacije bolesnika.

Bolesnici koji su nakon srčanog zastoja uspešno reanimirani, imaju lošiju prognozu i kao takvi nisu pogodni za dalji transport već se moraju zbrinuti u ustanovi u kojoj su se zatekli. Ovo podrazumeva i da služba HMP takve pacijente ne treba da preuzima za transport. U slučaju da je bolesnik hipotenzivan a indikovan je transport u drugu zdravstvenu ustanovu, jedna od terapijskih mogućnosti je i primena transfuzija krvi i krvnih derivata. Međutim transfuziloško lečenje često nije dostupno, što ne treba da odloži transport takvih bolesnika ukoliko se proceni da im ne preti srčani zastoj [38] .

Poboljšanju rezultata preživljavanja bolesnika sa RAAA doprinosi dostupnost krvi i krvnih derivata u ustanovi u kojoj se bolesnici operišu, postojanje aparata za spasavanje krvi (cell saver), izbegavanje hipotermije i izbegavanje prerane endotrahealne intubacije pacijenta [39].

Presudan faktor za poboljšanje rezultata lečenja RAAA je vreme, iz čega proizilazi da bi u inicijalnom tretmanu ovakvih bolesnika trebalo da postoji jasno definisana vremenska linija što zahteva uvođenje posebnih protokola za ovakve slučajeve [34-36]. Prema Vodiču udruženja za vaskularnu hirurgiju, preporučeno ciljno vreme od prvog kontakta sa bolesnikom do uspostavljanja hemostaze iznosi 90 minuta [40].

Još uvek nema dovoljno istraživanja koja su se bavila poređenjem preživljavanja bolesnika u kontekstu dužine transporta u adekvatnu zdravstvenu ustanovu [41,42] tako da je ovaj vremenski algoritam formiran na osnovu vodiča American College of Cardiology (ACC) Foundation/American Heart Association (AHA) u tretmanu infarkta miokarda sa ST elevacijom (STEMI) [43]. Celokupni period transporta je podeljen na tri dela po principu 30-30-30 minuta. Inicijalni period je vremenski period između prvog kontakta sa bolesnikom kod koga se sumnja na RAAA i donošenja odluke o transportu u adekvatan vaskularni hirurški centar radi definitivnog zbrinjavanja ovog stanja. Ovaj period je izuzetno značajan jer se u njemu, zbog odložene dijagnoze, može izgubiti dosta vremena ukoliko se bolesnik transportuje u ustanovu u kojoj mu ne može biti pružena pomoć zbog nemogućnosti postavljanja definitivne dijagnoze ili 
nepostojanja vaskularnog hirurškog tima. Ujedno je to i najslabija tačka celokupnog protokola i period u kome se gubi značajno više vremena od onoga koje protokol nalaže.

Zacrtani cilj od 30 minuta za prvi, inicijalni period, svakako treba preispitati, jer za razliku od preporučenog vremena za inicijalni tretman infarkta miokarda, kod koga mobilni kardiološki timovi dijagnozu mogu postaviti na osnovu EKG-a, za definitivnu dijagnozu RAAA potreban je aparat za MSCT I, iz kog razloga je u vanbolničkim uslovima, osim postavljanja kliničke sumnje nemoguće postaviti definitivnu dijagnozu.

Drugi period je vremenski period hitnog transfera bolesnika u odgovarajući centar u kome je moguće hirurško zbrinjavanje RAAA i podrazumeva obaveznu komunikaciju tima koji bolesnika transportuje sa timom koji bolesnika treba da prihvati i definitivno zbrine, transfer kompletne dokumentacije (elektronski ukoliko je moguće) i brigu o bolesniku tokom transporta.

Treći period podrazumeva evaluaciju pacijenta od strane vaskularnog hirurškog tima, analizu dostupnih dijagnostičkih modaliteta (MSCTa), transport pacijenta u operacionu salu i početak procedure kojom se uspostavlja kontrola nad krvarenjem iz rupturirane aneurizme. Alogaritam postupanja od prvog kontakta sa bolesnikom do uspostavljanja kontrole nad krvarenjem predstavljen je u figuri 1.

Organizovanim regionalnim transfer-sistemom zasnovanim na teritorijalnoj organizaciji, i dovoljnim brojem pravilno raspoređenih vaskularnih hirurških centara spremnih da prihvate bolesnike sa RAAA, za operativno zbrinjavanje može biti selektovano više od $95 \%$ bolesnika uz stopu preživljavanja od $67 \%$ [31] .

Neophodan uslov su dobra koordinaciju između ustanova i službi koji bolesnike upućuju i onih koje bolesnike primaju, pouzdana služba transporta bolesnika, pridržavanje vodiča dobre kliničke prakse tokom transporta i standardizovan proces zbrinjavanja u adekvatnom vaskularnom centru [43] .

\section{Zaključak}

Za sada ne postoji standardizovan i opšte prihvaćen sistem inicijalnog zbrinjavanja, kao ni sistem transporta pacijenata sa RAAA koji je univerzalno primenjiv u svim zdravstvenim sistemima.

Dalji ciljevi su definisanje najdužeg prihvatljivog vremena za zbrinjavanje pacijenata sa RAAA u uslovima našeg nacionalnog zdravstvenog sistema uz izradu algoritama za zbrinjavanja ovako teških bolesnika.

Sukob interesa: autori izjavljuju da nemaju sukob interesa.

\section{LITERATURA}

1. Hoornweg LL, Storm-Versloot MN, Ubbink DT, Koelemay MJ, Legemate DA, Balm R. Meta analysis on mortality of ruptured abdominal aortic aneurysms. Eur J Vasc Endovasc Surg. 2008; 35 (5):558-70. doi: $\quad 10.1016 /$ j.ejvs.2007.11.019. PMID:18226567.

2. Mureebe L, Egorova N, Giacovelli JK, Gelijns A, Kent KC, McKinsey JF. National trends in the repair of ruptured abdominal aortic aneurysms. J Vasc $\begin{array}{llll}\text { Surg. 2008; } 48 \text { (5): } 1101-7 . & \text { doi: }\end{array}$ 10.1016/j.jvs.2008.06.031. PMID: 18771883.

3. Johansen K, Kohler TR, Nicholls SC, Zierler RE, Clowes AW, Kazmers A. Ruptured abdominal aortic aneurysm: the Harborview experience. J Vasc Surg. 1991; 13(2): 240-5. discussion 245-7. PMID: 1990165.

4. Bengtsson H, Bergqvist D. Ruptured abdominal aortic aneurysm: a population-based study. J Vasc Surg. 1993; 18(1):74-80. PMID: 8326662.

5. Lindsay TF, Luo XP, Lehotay DC, Rubin BB, Anderson M, Walker PM, et al. Ruptured abdominal aortic aneurysm, a "two-hit" ischaemia/reperfusion injury: evidence from an analysis of oxidative products. J Vasc Surg. 1999; 30(2): 219-28. DOI: DOI: https://doi.org/10.1016/S0741-5214(99)70131$\mathrm{X}$.

6. Salman HE, Ramazanli B, Yavuz MM, Yalcin HC. Biomechanical Investigation of Disturbed Hemodynamics-Induced Tissue Degeneration in Abdominal Aortic Aneurysms Using Computational and Experimental Techniques Front Bioeng Biotechnol.2019; 7:111. doi: 10.3389/fbioe. 2019.00111. PMID: 31214581.

7. Gasser TC, Nchimi A, Swedenborg J, Roy J, Sakalihasan N, Böckler D, et al. A Novel Strategy to Translate the Biomechanical Rupture Risk of Abdominal Aortic Aneurysms to their Equivalent Diameter Risk: Method and Retrospective Validation. Eur J Vasc Endovasc Surg. 2014, 47(3): 288-95. 
https://doi.org/10.1016/j.ejvs.2013.12.018. PMID: 24456739.

8. Gloviczki P, Pairolero PC, Mucha P Jr, Farnell MB, Hallett JW Jr, Ilstrup DM, et al. Ruptured abdominal aortic aneurysms: repair should not be denied. J Vasc Surg. 1992; 15(5):851-7. discussion 857-9. PMID: 1578541.

9. Badger S, Forster R, Blair PH, Ellis P, Kee F, Harkin DW. Endovascular treatment for ruptured abdominal aortic aneurysm. Cochrane Database $\quad$ Syst Rev. 2017; 2017(5): CD005261. doi: 10.1002/14651858.CD005261.pub. PMCID: PMID: 28548204.

10. Lesperance K, Andersen C, Singh N, Starnes B, Martin MJ. Expanding use of emergency endovascular repair for ruptured abdominal aortic aneurysms: disparities in outcomes from a nationwide perspective. J Vasc Surg. 2008; 47(6): 1165-70. doi:10.1016/j.jvs.2008.01.055. PMID: 18394857.

11. Sweeting MJ, Balm R, Desgranges P, Ulug P, Powell JT, Ruptured Aneurysm Trialists.. Individual-patient meta-analysis of three randomized trials comparing endovascular versus open repair for ruptured abdominal aortic aneurysm. $\mathrm{Br} \quad \mathrm{J}$ Surg. 2015; 102(10):1229-39. doi: 10.1002/bjs.9852 PMID: 26104471.
12. Toskovic
B, Bilanovic
D, Resanovic

A, Todorovic S, Mrda D, Crnokrak B, et al. Management of major bile duct injuries following laparoscopic and open cholecystectomy - a single center experience. Srp Arh Celok Lek. 2019; 147(78):422-6.https://doi.org/10.2298/SARH190206030T.

13. Smidfelt K, Drott C, Törngren K, Nordanstig J, Herlitz J, Langenskiöld M. The Impact of Initial Misdiagnosis of Ruptured Abdominal Aortic Aneurysms on Lead Times, Complication Rate, and Survival. Eur J Vasc Endovasc Surg. 2017; 54: 21-7. DOI: https://doi.org/10.1016/j.ejvs.2017.03.022.

14. Khaw H, Sottiurai VS, Craighead CC, Batson RC . Ruptured abdominal aortic aneurysm presenting as symptomatic inguinal mass: report of six cases. J Vasc Surg.1986; 4(4):384-9. DOI: 10.1067/mva. 1986.avs0040384. PMID:3761483.

15. Crnokrak B. Tretman akutnog tromboflebitisa površinskih vena donjih ekstremiteta, rad uže specijalizacije. Beograd: Medicinski fakultet Univerziteta u Beogradu, 2016.
16. Crnokrak B, Zdravković D, Tošković B, Čolaković N. Tromboflebitis prepubičnih vena kod bolesnika sa aplazijom leve zajedničke i leve spoljašnje ilijačne vene - prikaz slučaja. Sanamed. 2020; 15(1). (In press). 10.24125/ sanamed.v15i1.376.

17. Rose J, Civil I, Koelmeyer T, Haydock D, Adams D. Ruptured abdominal aortic aneurysms: clinical presentation in Auckland 1993-1997. Aust N Z J Surg. 2001;71(6):341-4. PMID: 11409018.

18. Azhar B, Patel SR, Holt PJ, Hinchliffe RJ, Thompson MM, Karthikesalingam A. Misdiagnosis of ruptured abdominal aortic aneurysm: systematic review and meta-analysis. J Endovasc Ther. 2014;21(4):568-75. doi: 10.1583/13-4626MR.1. PMID: 25101588.

19. Zdravkovic D, Ivanovic N, Crnokrar B. Microinvasion: could it be sufficient diagnostic criteria for the optimal treatment decision? Breast Cancer Research and Treatment. 2019; 176:717. doi: 10.1007/s10549-019-05269-x. PMID: 31073793.

20. Richards JR, McGahan JP. Focused Assessment with Sonography in Trauma (FAST) in 2017: What Radiologists Can Learn. Radiology. 2017; 283(1): 30-48. doi: 10.1148/radiol.2017160107. PMID: 28318439.

21. Atkinson PR, Milne J, Diegelmann L, Lamprecht H, Stander M, et al. Does Point-of-Care Ultrasonography Improve Clinical Outcomes in Emergency Department Patients With Undifferentiated Hypotension? An International Randomized Controlled Trial From the SHoC-ED Investigators. Ann Emerg Med. 2018; 72(4): 478-89. doi: 10.1016/j.annemergmed.2018.04.002. PMID: 29866583

22. Valente T, Rossi G, Lassandro F, Rea G, Marino $\mathrm{M}$, Muto M, et al. MDCT evaluation of acute aortic syndrome (AAS). Br J Radiol. 2016; 89(1061): 20150825. doi:10.1259/bjr.20150825. PMID: 27033344.

23. Vu KN, Kaitoukov Y, Morin-Roy F, Kauffmann C, Giroux MF, Thérasse E, et al. Rupture signs on computed tomography, treatment, and outcome of abdominal aortic aneurysms. Insights Imaging. 2014;5(3):281-93. doi:10.1007/s13244-014-0327-3. PMID: 24789068.

24. Lloyd GM, Bown MJ, Norwood MG,Deb R, Fishwick G, Bell PR, et al. Feasibility of preoperative computer tomography in patients with 
ruptured abdominal aortic aneurysm: a time-to-death study in patients without operation. J Vasc Surg. 2004;39(4):788-91.DOI:

10.1016/j.jvs.2003.11.041. PMID: 15071442.

25. Badger S, Forster R, Blair PH, Ellis P, Kee F, Harkin DW. Endovascular treatment for ruptured abdominal aortic aneurysm. Cochrane Database Syst Rev. 2017;5:CD005261. doi: 10.1002/14651858. PMID: 28548204.

26. Mehta M, Taggert J, Darling RC. 3rd, Chang BB, Kreienberg PB, Paty PS, et al. Establishing a protocol for endovascular treatment of ruptured abdominal aortic aneurysms: outcomes of a prospective analysis. J Vasc Surg. 2006; 44(1): 1-8; discussion 8. PMID: 16828417.

27. Maeda K, Ohki T, Kanaoka Y. Endovascular Treatment of Various Aortic Pathologies: Review of the Latest Data and Technologies. Int $\mathrm{J}$ Angiol. 2018;27(2):81-91. doi: 10.1055/s-00381645881. PMID: 29896040

28. Rückert RI, Hanack U, Aronés-Gomez S, Yousefi S. [Aneurysms of the abdominal aorta and iliac arteries: paradigm shift -operative therapy, if possible endovascular?]. Chirurg. 2014;85(9):78290. [In German]. doi: 10.1007/s00104-014-2718X.. PMID: 25200628.

29. De Backer G, Lalic N, Lovic D, Milicic D, Milicic Davor, Crnokrak B, et al. Management of dyslipidaemia in patients with coronary heart disease: Results from the ESC-EORP EUROASPIRE $\mathrm{V}$ survey in 27 countries. Atherosclerosis. 2019; 285: 135-46. doi: 10.1016/ j.atherosclerosis.2019.03.014. PMID:31054483.

30. Mell MW, Wang NE, Morrison DE, and Hernandez-Boussard T. Interfacility transfer and mortality for patients with ruptured abdominal aortic aneurysm. J Vasc Surg. 2014; 60: 553-7. doi: 10.1016/j.jvs.2014.02.061. PMID: 24768368.

31. Hames H, Forbes TL, Harris JR, Lawlor DK, DeRose G, Harris KA. The effect of patient transfer on outcomes after rupture of an abdominal aortic aneurysm. Can J Surg. 2007;50(1):43-7. PMID: 17391616.

32. Briggs CS, Sibille JA, Yammine H, Ballast JK, Anderson W, Nussbaum T, et al. Short-term and midterm survival of ruptured abdominal aortic aneurysms in the contemporary endovascular era. $\mathbf{J}$ Vasc Surg. 2018;68(2):408-14.e1. doi: 10.1016/ j.jvs.2017.12.037. PMID: 29526377.
33. Ying AJ, Affan ET. Abdominal Aortic Aneurysm Screening: A Systematic Review and Me ta-analysis of Efficacy and Cost. Ann Vasc Surg. 2019;54:298-303.e3. doi: 10.1016/j.avsg.2018.05.044. PMID: 30081169.

34. Acher C, Acher CW, Castello Ramirez MC, Wynn M. Operative Mortality and Morbidity in Ruptured Abdominal Aortic Aneurysms in the Endovascular Age. Ann Vasc Surg. 2019 Oct 30. pii: S0890-5096(19)30928-8. doi: 10.1016/j.avsg. 2019.10.073. PMID: 31676380.

35. Karsan RB, Powell AG, Nanjaiah P, Mehta D, Valtzoglou V. The top 100 manuscripts in emergency cardiac surgery. Potential role in cardiothoracic training. A bibliometric analysis. Ann Med Surg (Lond). 2019;43:5-12. doi: 10.1016/ j.amsu.2019.05.002. PMID: 31193454.

36. Moreno DH, Cacione DG, Baptista-Silva JC. Controlled hypotension versus normoten sive resuscitation strategy for people with ruptured abdominal aortic aneurysm. Cochrane Database Syst Rev. 2018;6:CD011664. doi: 10.1002/14651858. PMID: 29897100.

37. Kawatani Y, Nakamura Y, Kurobe H, Suda Y, Hori T. Correlations of perioperative coagulopathy, fluid infusion and blood transfusions with survival prognosis in endovascular aortic repair for ruptured abdominal aortic aneurysm. World J Emerg Surg. 2016; 11:29. doi:10.1186/s13017-016-0087-0. PMID: 27330545.

38. Gemayel G, Montessuit M, Sierra J, Lahlaidi Sierra N, Bednarkiewicz M. Management of aortic aneurysms in the endovascular era. Rev Med Suisse. 2017;13(552):519-23. [In French]. PMID: 28714620.

39. Manzur M, Han SM, Dunn J, Elsayed RS, Fleischman F, Casagrande Y, et al. Management of patients with acute aortic syndrome through a regional rapid transport system $J$ Vasc Surg. 2017;65(1):21-9. doi: 10.1016/j.jvs.2016.08.081. PMID: 27707620.

40. Smidfelt K, Drott C, Törngren K, Nordanstig J, Herlitz J, Langenskiöld M. Eur J Vasc Endovasc Surg. 2017; 54(1): 21-7. doi: 10.1016/ j.ejvs.2017.03.022. PMID: 28526396.

41. Nault P, Brisson-Tessier C, Hamel D, Lambert L.J, and Blais C. A new metric for centralization of ruptured abdominal aortic aneurysm repair in large 
42. territories. J Vasc Surg. 2015; 62: 862-7 doi: 10.1016/j.jvs.2015.04.442. PMID: 26235138.

43. Chaikof EL, Dalman RL, Eskandari MK, Jackson BM, Lee WA, Mansour MA, et al. The Society for vascular Surgery practice guidelines on the care of patients with an abdominal aortic aneurysm. J Vascr Surg. 2018; 67(1): 2-77.e2. DOI: https://doi.org/ 10.1016/j.jvs.2017.10.044

44. Dehmer GJ, Blankenship JC, Cilingiroglu M, Dwyer JG, Feldman DN, Gardner TJ, et al. Society for Cardiovascular Angiography and Interventions; American College of Cardiology; American Heart
Association. SCAI/ACC/AHA Expert Consensus Document: 2014 Update on Percutaneous Coronary Intervention Without On-Site Surgical Backup. Catheter Cardiovasc Interv. 2014; 84(2):169-87. doi: 10.1002/ccd.25371. PMID: 25045090.

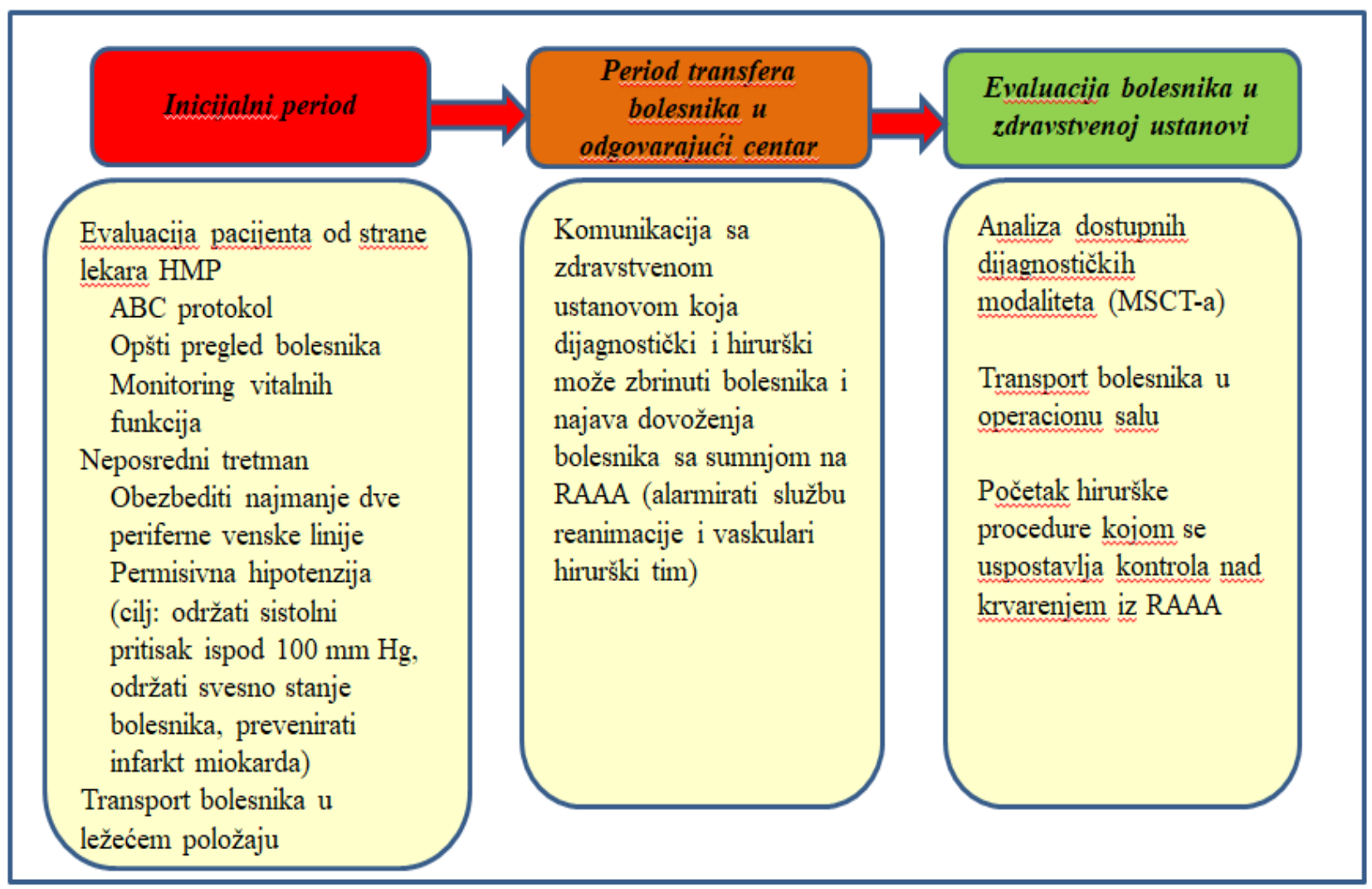

Figura 1. Algoritam postupanja od prvog kontakta sa bolesnikom do uspostavljanja kontrole nad krvarenjem 
- review article -

\title{
THE EMERGENCY MEDICAL TEAM'S ROLE IN INITIAL TREATMENT AND TRANSPORT OF PATIENTS WITH ABDOMINAL AORTIC ANEURYSM RUPTURE
}

\author{
Bogdan CRNOKRAK, Nataša ČOLAKOVIĆ, Darko ZDRAVKOVIĆ, Borislav TOŠKOVIĆ, Marija \\ ZDRAVKOVIĆ
}

UHMC Bezanijska kosa, Belgrade, Serbia

\begin{abstract}
Summary
An abdominal aortic aneurysm rupture (AAAR) is an acute, potentially fatal clinical condition which needs to be treated surgically as soon as possible. The process of making the diagnosis and providing treatment for patients with this clinical condition exceeds by far the resources and capabilities of the Emergency Medical Service. However, if the possibility of this diagnosis is taken into account during first contact, initial treatment and transport of these patients to the hospital, it is possible to significantly shorten the time before the patient is taken to the operating room and the bleeding put under control. This is crucial for the survival of these patients. Therefore, the Emergency Medical Service does not have a passive role in treating patients with this condition, but rather is a crucial link that enables an adequate initial treatment and quick transport to a hospital capable of providing surgical treatment and is key to their survival. A standardized and generally accepted system of initial care and transport that is universally applicable in all healthcare systems for patients with AAAR does not exist, but teamwork and addressing possible problems in providing adequate care on all levels does provide a larger number of patients with a chance to survive the condition that is almost synonimous to death.
\end{abstract}

\section{Keywords}

Aneurysm rupture, transport, Emergency Medical Service 